\title{
SMART GRID TECHNOLOGY, TRANSMISSION OF ELECTRICAL ENERGY IN POWER SUPPLY AND LIGHTING SYSTEMS OF CITIES
}

Modern power supply and lighting systems of cities are complex electrical systems of an automated type, in which the processes in individual power supply systems and city lighting systems are interconnected and interdependent. Therefore, the search for efficient technologies for the transmission of electrical energy in them is an extremely difficult task. The real state of the power supply and lighting systems in cities today is characterized by low operating efficiency, largely due to the low quality of electrical energy and insufficient compensation of reactive power in them. The mutual influence of power supply and lighting systems in cities, as well as the presence of significant voltage deviations and the overflow of additional reactive power in the networks, causes an increase in voltage and power losses in them, as well as a decrease in the efficiency of networks and connected consumers, in general. Unfortunately, the existing methods and technical means based on them cannot fully solve this problem. The research carried out made it possible to clarify the nature of the processes in the power supply systems and the sanitation of cities and to determine the methods and technical means based on the Smart Grid concept. They are based on the use of phase-shifting booster transformers with an electronic control system. Their use made it possible to provide the possibility of complex control of the voltage modes of active and reactive power with the possibility of installation at any point in the network and centralized control from a single centre. The calculations show that the use of the developed methods and technical means provides an opportunity to reduce power losses in networks by $10-15 \%$ and energy costs for consumers by $50-75 \%$.

Keywords: smart grid technology, transmission of electrical energy, power supply, lighting systems, efficiency, electrical energy.

\section{П. П. ГОВОРОВ, К. В. ГОВОРОВА, А. К. КІНДІНОВА, О. АБДЕЛЬРАХІМ}

\section{SМАRT GRID TЕХНОЛОГÏ̈, ПЕРЕДАЧА ЕЛЕКТРИЧНОЇ ЕНЕРГІЇ В СИСТЕМАХ ЕЛЕКТРОПОСТАЧАННЯ ТА ОСВІТЛЕННЯ МІСТ}

Сучасні системи електропостачання та освітлення міст являють собою складні електротехнічні системи автоматизованого типу, в яких процеси в окремо взятих системах електропостачання та системах освітлення міст є взаємопов'язаними та взаємозалежними. Тому пошук ефективних технологій передавання електричної енергії в них є задачею надзвичайної складності. Реальний стан систем електропостачання та освітлення міст сьогодні характеризується низькою ефективністю роботи, що в значній мірі пов'язано з низькою якістю електричної енергії та недостатньою компенсацією реактивної потужності в них. Взаємний вплив систем електропостачання та освітлення міст, а також наявність значних відхилень напруги і перетікання додаткової кількості реактивної потужності в мережах обумовлює підвищення втрат напруги і потужності в них, а також зниження ефективності роботи мереж і підключених споживачів, в цілому. На жаль, існуючі методи і технічні засоби, засновані на них, не можуть вирішити цю проблему в повній мірі. Проведені дослідження дозволили уточнити характер процесів в системах електропостачання та освітлення міст і визначити методи і технічні засоби, засновані на концепції Smart Grid. B їх основу покладено застосування фазоперемикаємих вольтододавальних трансформаторів 3 електронною системою управління. Їх застосування дозволило забезпечити можливість комплексного управління режимами напруги активної і реактивної потужності з можливістю установки в будь-якій точці мережі і централізованим управлінням з єдиного центру. Проведені розрахунки свідчать про те, що застосування розроблених методів і технічних засобів надає можливість зменшення втрат потужності в мережах на 10-15\% і витрати енергії у споживачів 50-75\%.

Ключові слова: технологія smart grid, передача електроенергії, електропостачання, системи освітлення, ефективність, електрична енергія.

Ф. П. ГОВОРОВ, К. В. ГОВОРОВА, А. К. КИНДИНОВА, О. АБДЕЛЬРАХИМ

\section{SMART GRID TЕХНОЛОГИИ, ПЕРЕДАЧА ЭЛЕКТРИЧЕСКОЙ ЭНЕРГИИ В СИСТЕМАХ ЭЛЕКТРОСНАБЖЕНИЯ И ОСВЕЩЕНИЯ ГОРОДОВ}

Современные системы электроснабжения и освещения городов представляют собой сложные электротехнические системы автоматизированного типа, в которых процессы в отдельно взятых системах электроснабжения и системах освещения городов взаимосвязаны и взаимозависимы. Поэтому поиск эффективных технологий передачи электрической энергии в них является задачей чрезвычайной сложности. Реальное положение систем электроснабжения и освещения городов сегодня характеризуется низкой эффективностью работы, в значительной степени связано с низким качеством электрической энергии и недостаточной компенсацией реактивной мощности в них. Взаимное влияние систем электроснабжения и освещения городов, а также наличие значительных отклонений напряжения и перетекание дополнительного количества реактивной мощности в сетях обусловливает повышение потерь напряжения и мощности в них, а также снижение эффективности работы сетей и подключенных потребителей, в целом. К сожалению, существующие методы и технические средства, основанные на них, не могут решить эту проблему в полной мере. Проведенные исследования позволили уточнить характер процессов в системах электроснабжения и освещения городов и определить методы и технические средства, основанные на концепции Smart Grid. B их основу положено применение фазопереключаемых вольтодобавочного трансформаторов с электронной системой управления. Их применение позволило обеспечить возможность комплексного управления режимами напряжения активной и реактивной мощности с возможностью установки в любой точке сети и централизованным управлением из единого центра. Проведенные расчеты свидетельствуют о том, что применение разработанных методов и технических средств предоставляет возможность уменьшения потерь мощности в сетях на $10-15 \%$ и затраты энергии у потребителей 50-75\%.

Ключевые слова: технология smart grid, передача электроэнергии, электроснабжение, системы освещения, эффективность, электрическая энергия. 
Introduction. Modern power supply and lighting systems in cities are complex geographically distributed systems, which, in turn, are part of higher-level systems electric power systems or their various subsystem levels. They have common elements with them (supply and distribution networks of high and medium voltage), as well as power supplies and means of regulation and control. This makes them mutually influencing and interdependent, requires the use of methods and technical means of control, adapted to the parameters and modes of urban energy systems. To control the modes of electrical networks, mainly methods and technical means based on discrete, mainly manual control are used. However, more and more human-machine automated systems are used. They have a more flexible structure and advanced functions, moreover, in recent years there has been a rethinking of the problem of automation, and instead of optimizing individual functions and processes, I increasingly consider the processes in a complex, with a systematic approach to solving the problem as a whole.

Analysis of the state of the matter. Therefore, a further increase in requirements for the efficiency of energy production dictates the need for comprehensive automation of technological processes in power supply and lighting systems in cities through the automation of processes at the level of transformation of parameters and type of electricity $[1,2]$. At the same time, the spatial and hourly distribution of processes in the power supply and lighting systems of cities in combination with discrete manual control makes the solution of this problem quite difficult. In these conditions, a systematic approach opens up wide opportunities, which allows one to dismember power supply systems into separate interconnected elements that interact to achieve the set global goal. Its use makes it possible to combine electrical networks into a single flexible geoinformation control system of an intelligent type, optimization of modes that opens up opportunities for using huge reserves, for the rational use of material and energy resources [3].

Research methods. As a basis for building such systems, multilevel hierarchical distributed structures are considered, the effectiveness of which has been confirmed by practice. In such structures, the functions of higher coordination and organizational management, in general, are performed by the upper level of the hierarchy. In the systems of power supply and lighting of cities, this is an operational information and control complex, which is part of the automated control system of an energy association

As an element of the energy system, the power supply and lighting system of cities, together with other consumers connected to the power centre, form it and the resulting load schedule, as well as the laws of voltage regulation and reactive power compensation $[4,5]$. Optimization of the complex operation requires coordinated management of the operating modes of all consumers using a set of local and global criteria. On the basis of local criteria, optimal operating conditions for individual local objects are provided, and through global ones - the operating conditions of the system as a whole. In this case, in the event of a conflict situation, priority is given to the global criterion. The presence of these features necessitates the use of systemic control of modes in the power supply and lighting systems of cities of multilevel multi-criteria control systems built on a multi-loop hierarchical principle $[5,6]$. Decision-making processes in such systems have a wide range - from very short management actions to planning processes for a long period. For these reasons, in the systems under consideration, there are differences in the duration of cycles, criteria and control parameters at different territorial and hourly levels.

The analysis of the functional tasks of the power supply and lighting systems of cities indicates the possibility of integrating their control systems into the systems of energy complexes. However, as evidenced by the results of the analysis, a simple transfer of the ideology of constructing management tools for energy systems at higher levels cannot be applied to power supply and lighting systems in cities due to the operational, technological, and socio-ecological features of power supply and lighting systems.

The problems of controlling the modes of power supply and lighting systems in cities include the lack of a sufficient number of control channels. This is a small number of telephone communication channels with separate RP, TP or IP, focused on performing simple functions of discrete control. In some cases, VHF or GSM communication channels are used in a limited frequency range. It should also be noted that there are no continuous control systems for $0.4-10 \mathrm{kV}$ facilities.

The developed concept of control over the modes of power supply systems for city lighting is based on a hierarchical multi-level aggregated structure [5]. At the lower levels, the control system is represented by a large number of local systems, which are characterized by relative independence of functioning, adapted for use in the nodes of network loads. For them, the most effective is the stabilization of the parameters of the technological process with the help of active elements. The structure of such control systems is distributed in nature (Fig. 1). Its active elements, which carry out the correction of the mode parameters, as close as possible to the control objects. ideally, they are installed directly at the load nodes of the networks.

Results. In the considered control system, a number of sequential decision-making levels are distinguished, at each of which information is processed, which comes from the elements of the lower level. Their goal is to develop coordinating actions for the elements of this level. The point of allocation of decision-making levels is made in accordance with the vertical decomposition of the control system. Based on the results of modelling the modes [7] and in accordance with $[8,9]$, the following control levels have been identified in the power supply and lighting systems of cities: lighting control point, TP, RP, SS 35-110 kV and power supply and lighting systems of cities, in general. Each of them has its own duration, criteria and control parameters. The allocation of functional tasks, the solution of which is not related to other tasks of this level, corresponds to the horizontal decomposition of the control system. The horizontal decomposition of the lower levels of the control system corresponds to the allocation of local control systems, which can be controlled in an autonomous 
mode. The number of local control systems is determined by the structure of networks, technical content and territorial location of its elements.

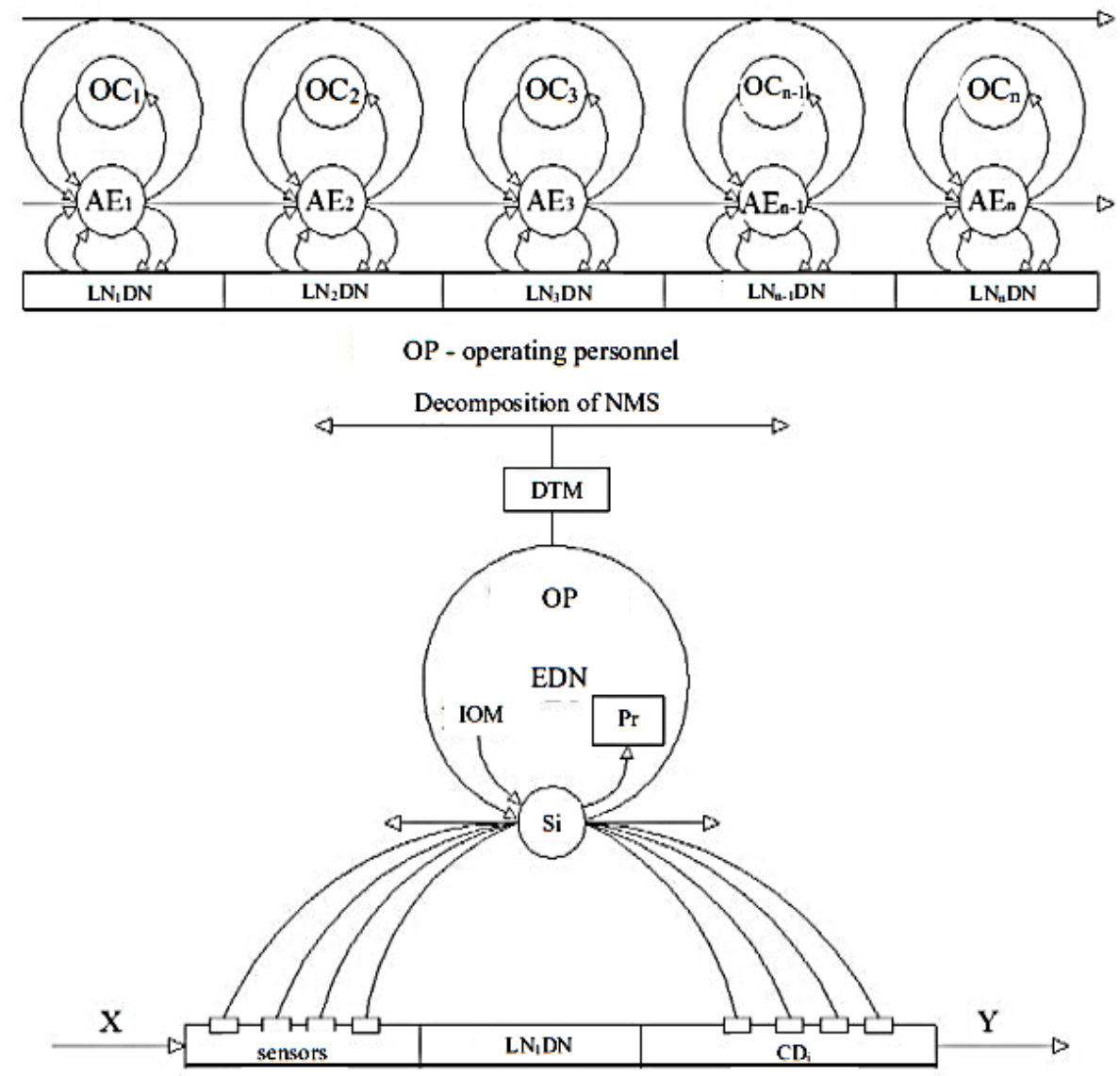

Figure 1 - Structural decomposition of the network management system: $\mathrm{Pr}$ - processor; IOM - input-output module; OC - object controller; DTM - data transmission multiplexer; AE - active element

At the same time, information transformation operations that are established can be considered as algorithmic functions, which are a kind of modules from which a control algorithm can be added. This primarily applies to typical elements. Those that perform certain algorithmic functions. The signs of the typification of the control system of its elements can be their orientation, information power, target orientation, and so on. In the work, for the typification of control systems and its elements, an objectively oriented feature was adopted, which provides the possibility of static analysis and forecasting of the development of the RM control system, the management of individual objects, as well as the most accurate state of the list of necessary algorithmic functions, to assess the composition of the control system parameters, to formulate the basic requirements for technical means [10-12]. In these conditions, the concept of a typical control system is reduced to a typical functional structure of a control system, which can be represented by a display:

$$
F: X \times \bar{f} \rightarrow Y,
$$

where $\quad \mathrm{F}-\mathrm{a}$ set of algorithmic functions;

$\mathrm{X}$ - an input signal;

$\mathrm{Y}-$ an output signal.
Further detailing of the operation algorithm of the control system can be performed using their contour decomposition, which is based on the presence in the local control system of several nodes for collecting and processing information, connected in a certain way by active elements. At the same time, decision-making in the developed control system is based on a multilayer principle, according to which a complex control problem is divided into a family of sequentially connected more substantive problems. The decision made in each previous layer forms the basis for the decision in the subsequent layer. Solving a problem, in general, is a consistent solution to its constituent problems. This corresponds to the time distribution of the operation to control the parameters of the network mode. In this case, the information nodes carry out a cyclical exchange of information between the load nodes and active elements. Each cycle uses additional information that is obtained over longer time intervals. As such, signals from active elements, various kinds of static data, etc. are used. The use of phase-switched booster transformers is proposed as an active element (Fig. 2) [13, 14]. This creates the possibility for complex unconnected voltage regulation of reactive potential [15].

Conclusion. In general, the proposed concept of managing the modes of power supply and lighting systems in cities allows taking into account their features associated 
with accounting adjacent systems. In such conditions, taking into account the noted features makes it necessary to separate the power supply and lighting systems of cities into an independent Smart Grid city life support system. It includes the electric power system and power supply and lighting systems of cities, representing a set of power and lighting installations with a control system built based on the Smart Grid concept, as an integral part of the city's life support system, including their fauna and flora. The application of the considered basic provisions allows returning to the main goal of creating technical systems to meet the human demand for a comfortable living environment as a means of human life support.

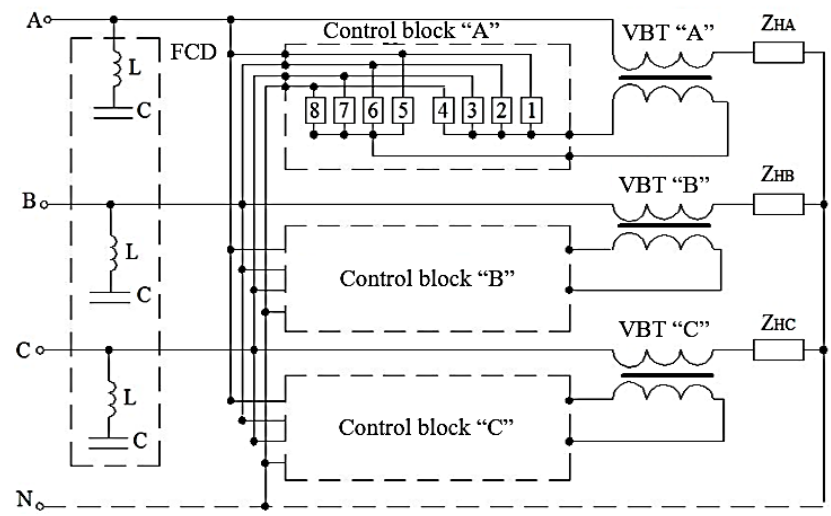

$a$

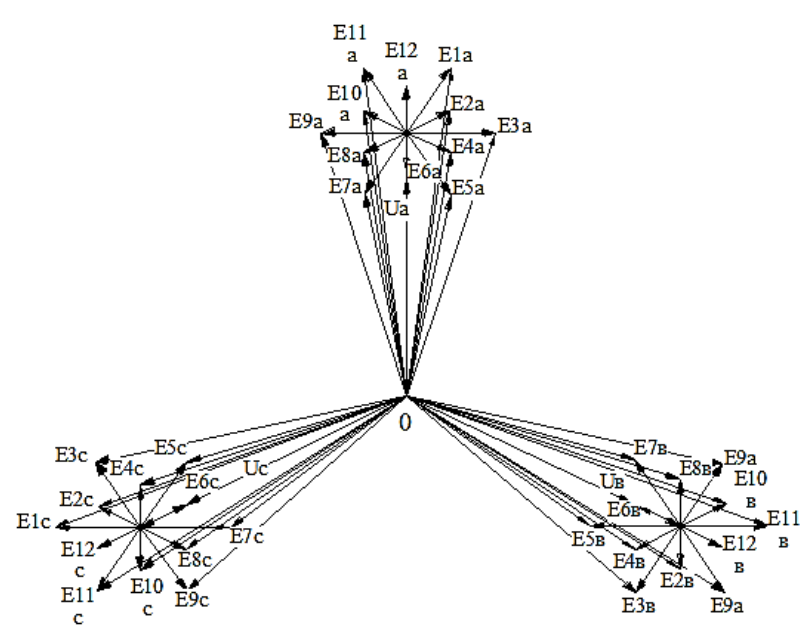

$b$

Figure 2 - An active element based on a phase-switched booster transformer: $a$-connection diagram, $b$ - vector diagram

\section{References}

1. Шидловский А. К., Кузнецов В. Г. Повышение качества энергии в электрических сетях. Киев: Наукова думка, 1985. 268 с.

2. Golub I. V., Zaitsev D. A., Tyrshu M. S. Modes of a reactive power source controlled by a phase-shifting transformer. Problemele energeticii regionale. 2018. No. 2 (37). P. 62-69.

3. Назаров В. В. Концепция Smart Grid и реальная энергетика Енергетика та Електрифікація. 2013. № 6 (358). С. 12-15.

4. Говоров Ф. П., Говоров В. Ф. Управление потоками активной и реактивной мощностей в электрических сетях. Технічна електродинаміка. 2016. № 5. С. 61-63. doi: 10.15407/techned2016.05.061

5. Говоров Ф. П., Говорова Е. В., Дюмин Э. С. Интеллектуальные гибкие системы управления режимами работы городских электрических сетей. Управляемые электропередачи: сборник cтатей № 9. Кишинев: Институт Энергетики. 2017. № 8. С. 162 191.

6. Hovorov P., Bakulevskiy V. Improvement of the mathematical mode for calculating and predicting the loss of electricity on the basis of neural networks. International scientific conference Unitech 2017. Gabrovo, Bulgaria. 2017. P.59-63.

7. Говоров П. П., Бакулевський В. Л. Поліпшення математично моделі розрахунку та прогнозування втрат електроенергії на основі нейронних мереж. Вісник Вінницького політехнічного інституту. 2018. № 2 (137). С. 14-19.

8. Ясутис А. В. Анализ работы вольтодобавочного трансформатора с тиристорным управлением. Труды Всесоюзного заочного политехнического института. 1973. Вып. 84. С.146-156.

9. Говоров Ф.П. Режимы работы $u$ особенности елетромагнитних проиессов вольтодобавачного трансформатора с тиристорным управлением: дис. ... канд.тех.наук: 05.09.01. Ленинград, 1983. 229 с.

10. Hovorov P. P., Hovorov V. P., Kindinova A. K., Abdelrahim O. Study mode voltage booster transformer with thyristor control. Internationa Scientific Conference Unitech 2019. Gabrovo, Bulgaria. 2019. P. 8993

11. Говоров П. П.,, Новський В. О., Говоров В. П., Кіндінова А. К Керування режимами розподільних електромереж міст в умовах слабкої кореляції графіків активної та реактивної потужностей. Технічна електродинаміка. 2020. № 4. С. 60-66. doi 10.15407/techned2020.04.060

12. Hovorov P., Hovorov V., Kindinova A., Abdelrhim O. Developmen of model voltage booster transformers parameters. 2020 IEEE KhPI Week on Advanced Technology (KhPIWeek). Kharkiv, Ukraine. 2020. P. 211-216. doi: 10.1109/KhPIWeek51551.2020.9250136

13. Говоров Ф. П., Говоров В. Ф. Компенсация реактивной мощности в системах электроснабжения и освещения городов. Наукові праці Донецького національного технічного університету. Серія: Електротехніка $і$ енергетика. 2013 № 1 (14). C.71-76.

14. Говоров Ф. П., Говоров В. Ф., Романова Т. И. Управление потоками электрической энергии в сетях с помощью фазопереключаючих вольтодобавочных трансформаторов. Energy of Moldova - 2016. Regional Aspects of Development Chisinau, Moldova. 2016. P. 363-368.

15. Говоров Ф. П., Говоров В. Ф., Король О. В. Повышение надежности работы вольтодобавочных трансформаторов с электронным управлением в составе ESS. Вестник Национального технического университета «Харьковскии политехнический институт. Серия: Проблемь автоматизированного электропривода. Теория и практика. 2015. № 12 (1121). C. 484-489.

\section{References (transliterated)}

1. Shidlovskiy A. K., Kuznetsov V. G. Povyshenie kachestva energii v elektricheskikh setyakh [Improving the quality of energy in electrical networks]. Kyiv, Naukova dumka Publ., 1985, 268 p.

2. Golub I. V., Zaitsev D. A., Tyrshu M. S. Modes of a reactive powe source controlled by a phase-shifting transformer. Problemele energeticii regionale. 2018. No. 2 (37). P. 62-69.

3. Nazarov V. V. Kontseptsiya Smart Grid i real'naya energetika [The concept of Smart Grid and real power engineering]. Energy and Electrification. 2013, No. 6 (358), pp. 12-15.

4. Govorov F. P., Govorov V. P. Upravlenie potokami aktivnoj i reaktivnoj moshhnostej $\mathrm{v}$ jelektricheskih setjah [Flow control active and reactive power in electric networks]. Technical Electrodynamics 2016, no. 5, pp. 61-63. doi: 10.15407/techned2016.05.061

5. Govorov F. P., Govorova E. V., Dyumin E. S. Intellektual'nye gibkie sistemy upravleniya rezhimami raboty gorodskikh elektricheskikh seteyyu [Intelligent flexible control systems for urban electrical networks]. Upravlyaemye elektroperedachi: sbornik statey № 9 [Controlled power transmission: Collection of works №9]. Chisinau, Institute of Power Engineering Publ., 2017, no 8, pp. 162-191.

6. Hovorov P., Bakulevskiy V. Improvement of the mathematical model for calculating and predicting the loss of electricity on the basis of neural networks. International scientific conference Unitech'17. Gabrovo, Bulgaria. 2017, pp.59-63.

7. Hovorov P. P., Bakulevskyi V. L. Polipshennya matematychnoyi modeli rozrakhunku ta prohnozuvannya vtrat elektroenerhiyi na 
osnovi neyronnykh merezh [Improvement of mathematical model of calculation and power loss forecasting on the basis of neural networks]. Visnyk of Vinnytsia Polytechnical Institute. 2018, no. 2 (137), pp. 14-19.

8. Yasutis A. V. Analiz raboty vol'todobavochnogo transformatora s tiristornym upravleniem [Analysis of the operation of a booster transformer with thyristor control]. Proceedings of the All-Union Correspondence Polytechnic Institute. 1973, Vol. 84, pp.146-156.

9. Govorov F. P. Rezhimy raboty $i$ osobennosti eletromagnitnikh protsessov vol'todobavachnogo transformatora $s$ tiristornym upravleniem: dis. ... kand.tekh.nauk: 05.09.01 [Modes of operation and features of electromagnetic processes of a booster transformer with thyristor control. Candidate eng. sci. diss. (Ph. D.)]. Leningrad, 1983. $229 \mathrm{p}$.

10. Hovorov P. P., Hovorov V. P., Kindinova A. K., Abdelrahim O. Study mode voltage booster transformer with thyristor control. International Scientific Conference Unitech 2019. Gabrovo, Bulgaria. 2019. P. 89 93.

11. Govorov P. P., Novskiy V. O., Govorov V. P., Kindinova A. K. Keruvannya rezhymamy rozpodil'nykh elektromerezh mist $v$ umovakh slabkoyi korelyatsiyi hrafikiv aktyvnoyi ta reaktyvnoyi potuzhnostey [Management of modes of distributive electric networks of cities under conditions of weak correlation of graphics of active and reactive power]. Technical Electrodynamics. 2020, no. 4, pp. 60 66. doi: 10.15407/techned2020.04.060
12. Hovorov P., Hovorov V., Kindinova A., Abdelrhim O. Development of model voltage booster transformers parameters. 2020 IEEE KhPI Week on Advanced Technology (KhPIWeek). Kharkiv, Ukraine. 2020. P. 211-216. doi: 10.1109/KhPIWeek51551.2020.9250136

13. Govorov F. P., Govorov V. F. Kompensacija reaktivnoj moshhnosti v sistemah jelektrosnabzhenija i osveshhenija gorodov [Compensation of reactive power in power supply and lighting systems of cities]. Scientific Papers of Donetsk National Technical University. Series. "Electrical and Power Engineering". 2013, no. 1 (14). pp. 71-76.

14. Govorov F., Govorov V., Romanova T. Upravlenie potokami jelektricheskoj jenergii v setjah s pomoshh'ju fazoperekljuchajuchih vol'todobavochnyh transformatorov [The control of fluxes of electric power in the networks by means of phase-switching booster transformers]. Energy of Moldova - 2016. Regional Aspects of Development. Chisinau, Moldova. 2016, pp. 363-368.

15. Govorov F. P., Govorov V. F., Korol' O. V. Povyshenie nadezhnosti raboty vol'todobavochnyh transformatorov $s$ jelektronnym upravleniem $\mathrm{v}$ sostave ESS [Improving the reliability of voltage transformers with electronic control in the ESS]. Bulletin of the National Technical University "KhPI". Series: Problems of automated electrodrive. Theory and practice. 2015, no. 12 (1121), pp. 484-489.

Received 18.11.2020

\section{Відомості про авторів / Сведения об авторах / About the Authors}

Говоров Пилип Парамонович (Говоров Филипп Парамонович, Ноvorov Pylyp Paramonovych) - доктор технічних наук, професор, Харківський національний університет міського господарства імені О. М. Бекетова, професор кафедри світлотехніки та джерел світла, керівник Центру Енергетики та ресурсозбереження; Харків, Україна; ORCID: https://orcid.org/0000-0002-0379-1448.

Говорова Катерина Владленівна (Говорова Катерина Владленовна, Hоvоrova Kateryna Vladlenivna) Харківський національний університет міського господарства імені О. М. Бекетова, аспірантка; Харків, Україна; ORCID: https://orcid.org/0000-0002-0893-8605.
Кіндінова
Анастасія
Костянтинівна(Киндинова
Анастасия
Константиновна,

Kindinova Anastasiia Kostyantynivna) - Харківський національний університет міського господарства імені O. М. Бекетова, студентка; Харків, Україна; ORCID: https://orcid.org/0000-0003-2575-0767.

Омер Абдельрахім (Омэр Абдельрахим, Omer Abdelrahim) - Харківський національний університет міського господарства імені О. М. Бекетова, аспірант; Харків, Україна. 